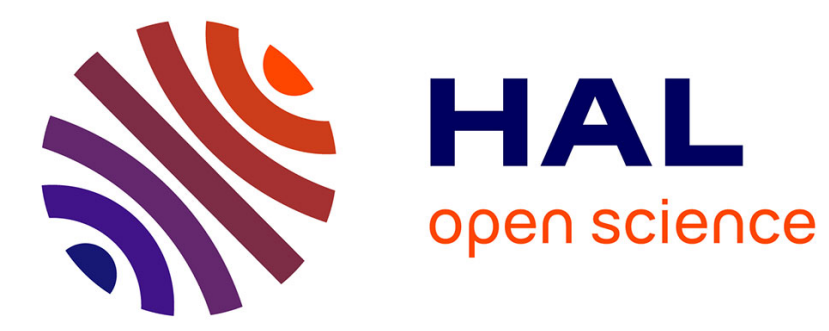

\title{
DYNAMICS OF SIMPLE FLUIDS BY INTERMOLECULAR LIGHT SCATTERING
}

\author{
P. Fleury
}

\section{To cite this version:}

P. Fleury. DYNAMICS OF SIMPLE FLUIDS BY INTERMOLECULAR LIGHT SCATTERING. Journal de Physique Colloques, 1972, 33 (C1), pp.C1-264-C1-264. 10.1051/jphyscol:1972144 . jpa00214934

\section{HAL Id: jpa-00214934 \\ https://hal.science/jpa-00214934}

Submitted on 1 Jan 1972

HAL is a multi-disciplinary open access archive for the deposit and dissemination of scientific research documents, whether they are published or not. The documents may come from teaching and research institutions in France or abroad, or from public or private research centers.
L'archive ouverte pluridisciplinaire HAL, est destinée au dépôt et à la diffusion de documents scientifiques de niveau recherche, publiés ou non, émanant des établissements d'enseignement et de recherche français ou étrangers, des laboratoires publics ou privés. 


\title{
DYNAMICS OF SIMPLE FLUIDS BY INTERMOLECULAR LIGHT SCATTERING
}

\author{
P. A. FLEURY
}

Bell Laboratories, Murray Hill, New Jersey, USA.

\begin{abstract}
Résumé. - On a démontré récemment [1] que les variations de polarisabilité qui accompagnent les collisions intermoléculaires peuvent produire une contribution détectable au spectre de la lumière diffusée inélastiquement par un fluide. Dans le cas le plus simple d'un gaz monoatomique relativement dilué les variations de polarisabilité sont dominées par les collisions binaires, et le spectre de la lumière diffusée s'étend sur un domaine de fréquence caractéristique de la durée $\tau$ d'une collision binaire. Les valeurs typiques de $\tau$ sont de l'ordre de $10^{-12}-10^{-13} \mathrm{~s}$ : de sorte que la diffusion intermoléculaire de la lumière représente un moyen puissant pour tester la dynamique sur des temps courts des interactions moléculaires. On a obtenu [2] une compréhension quantitative du spectre intermoléculaire dans les systèmes dominés par les collisions binaires, principalement parce qu'on peut calculer en détail la dynamique d'une collision binaire.

Par contre, beaucoup des prédictions de tels calculs ne s'appliquent plus à mesure que la densité du fluide croît. En particulier, des expériences sur l'argon sur du liquide et de la vapeur coexistant, ont révélé des écarts frappants par rapport au modèle des collisions binaires, en ce qui concerne la forme, la fréquence caractéristique et l'intensité du spectre intermoléculaire pour le liquide [3].

Malheureusement en l'absence d'une théorie dynamique d'un liquide ou d'un fluide dense, il n'est pas encore possible de faire un calcul quantitatif du spectre attendu. Cependant, on peut faire des progrès considérables en regardant la diffusion intermoléculaire comme une généralisation de la diffusion Raman du second ordre, familière depuis longtemps dans le cas des solides. Le succès semiquantitatif de ce point de vue dans l'argon liquide [3] suggère que la relation proposée entre le spectre intermoléculaire et les aspects concernés de la dynamique du fluide (à savoir les fonctions de corrélation de temps et d'espace) est fondamentalement correcte.

Après avoir discuté les résultats précédents dans le gaz dilué d'une part et le liquide de l'autre, nous présenterons les résultats de nouvelles expériences de diffusion intermoléculaire đans plusieurs gaz rares dans de larges domaines de température et de densité. Dans l'argon par exemple, on a fait varier la densité entre 100 amagats $(P=100 \mathrm{Atm})$ et 1000 amagats $(P=10000 \mathrm{Atm})$, à des températures entre $150^{\circ}$ et $300^{\circ} \mathrm{K}$; tandis que dans le néon on a étudié des densités jusqu'à 1800 amagats et des températures jusqu'à $38^{\circ} \mathrm{K}$. La forme spectrale et la fréquence caractéristique présentent une dépendance significative par rapport à $\rho$ et à $T$; elles sont particulièrement intéressantes pour des densités supérieures à celle du liquide normal.
\end{abstract}

Abstract. - It has been demonstrated recently [1] that the polarizability changes accompanying intermolecular collisions can produce a detectable contribution to the spectrum of light inelastically scattered by a fluid. In the simplest case of a relatively dilute monatomic gas the polarizability changes are dominated by binary collisions and the scattered light spectrum extends over a frequency range characteristic of the duration, $\tau$, of a binary collision. Typical values of $\tau$ are of order $10^{-12}$ $10^{-13} \mathrm{~s}$ : so that intermolecular light scattering represents a powerful means of probing the short time dynamics of molecular interactions. Quantitative understanding of the intesmolecular spectrum has been achieved [2] in binary collision dominated systems, chiefly because the dynamics of the binary collision can be calculated in detail.

Many of the predictions of such calculations fail, however, as the density of the fluid is increased. In particular, experiments on co-existing gaseous and liquid argon revealed striking departures from the binary collision picture with regard to the shape, characteristic frequency and intensity of the intermolecular spectrum for the liquid [3].

Unfortunately in absence of a dynamic theory of the liquid or dense fluid state a quantitative calculation of the anticipated spectrum is not yet possible. Considerable progress can be made, however, by viewing the intermolecular scattering in a dense fluid as a generalization of the secondorder Raman scattering long familiar in solids. Semiquantitative success of this viewpoint in liquid argon [3] suggests the proposed relation between the intermolecular spectrum and the relevant aspects of the fluid's dynamics (i. e. space and time correlation functions) is basically correct.

In addition to discussing earlier results in the dilute gas on the one hand, and the liquid on the other, we will present results of new intermolecular scattering experiments on several noble gas fluids over a wide range of temperatures and densities [4]. In argon for example, density was varied between 100 amagats $(P=100 \mathrm{Atm})$ and 1000 amagats $(P=10000 \mathrm{Atm})$, at temperatures between $150^{\circ}$ and $300 \circ \mathrm{K}$ : while in neon densities up to 1800 amagats and temperatures down to $38 \circ \mathrm{K}$ were studied. The spectral shape and characteristic frequency exhibit significant dependence on both $\rho$ and $T$ and are particularly interesting at densities higher than the normal liquid density.

\section{References}

[1] Mctague (J. P.) and Birnbaum (G.), Phys. Rev. Letters, $1968,21,661$.

[2] Lallemand (P. M.), Phys. Rev. Letters, 1970, 25, 1079 ; Gersten (J. I.), Slusher (R. E.) and Surko (C. M.), Phys. Rev. Letters, 1970, 25, 1739.
[3] Mctague (J. P.), Fleury (P. A.) and DuPre (D. B.), Phys. Rev. 1969, 188, 303.

[4] Fleury (P. A.), Daniels (W. B.) and Worlock (J. M.), Bull. Am. Phys. Soc., 1971, 16, 28 ; Phys. Rev. Letters, 1971, 27, 14.93. 